\title{
NUMERICAL SIMULATION OF YIELDING SUPPORTS IN THE SHAPE OF ANNULAR TUBES UNDER STATIC AND SHORT-TERM DYNAMIC LOADING
}

\author{
Oleg G. Kumpyak, Nikita V. Mescheulov \\ Tomsk State University of Architecture and Building, Tomsk, RUSSIA
}

\begin{abstract}
Occurrence of extreme man-made impacts on buildings and structures has become frequent lately as a consequence of condensed explosives or explosive combustion of gas- vapor or air-fuel mixtures. Such accidents involve large human and economic losses, and their prevention methods are not always effective and reasonable. The given research aims at studying the way of enhancing explosion safety of building structures by means of yielding supports. The paper presents results of numerical studies (finite element, 3D nonlinear) of strength and deformability of yielding supports in the shape of annular tubes under static and short-term dynamic loading. The degree of influence of yielding supports was assessed taking into account three peculiar stages of deformation: elastic; elasto-plastic; elasto-plastic with hardening. The methodology for numerical studies performance was described. It was established that rigidity of yielding supports influences significantly their stress-strain state. The research determined that with increase of deformable elements rigidity dependency between load and deformation of yielding supports in elastic and plastic stages have linear character. Significant reduction of dynamic response and increase of deformation time of yielding supports was observed by increasing the plastic component. Therefore it allows assuming on possibility of their application as supporting units in reinforced concrete constructions.
\end{abstract}

Keywords: yielding supports, strength, deformability, numerical simulation, finite element method, explicit dynamic, nonlinear effects

\section{ЧИСЛЕННОЕ МОДЕЛИРОВАНИЕ ПОДАТЛИВЫХ ОПОР В ВИДЕ ТРУБ КОЛЬЦЕВОГО СЕЧЕНИЯ ПРИ СТАТИЧЕСКОМ И КРАТКОВРЕМЕННОМ ДИНАМИЧЕСКОМ НАГРУЖЕНИИ}

\author{
О.Г. Кумпяк, Н.В. Мещеулов \\ Томский государственный архитектурно-строительный университет, г. Томск, РОССИЯ
}

\begin{abstract}
АННОТАЦИЯ: В последнее время участились случаи экстремальных техногенных воздействий на здания и сооружения, например, вследствие взрыва конденсированных взрывчатых веществ либо взрывного горения газо-, паро- или пылевоздушных смесей. Такие события могут повлечь большие человеческие и экономические потери, а методы их предотвращения или снижения последствий не всегда эффективны и рациональны. Целью данной работы является изучение способа повышения взрывобезопасности строительных конструкций за счет применения податливых опор. Представлены результаты численных (конечноэлементных, в трехмерной нелинейной постановках) исследований прочности и деформативности податливых опор в виде труб кольцевого сечения при статическом и кратковременном динамическом нагружении. Произведена оценка степени влияния податливых опор, имеющих три характерные стадии деформирования: упругая; упруго-пластическая; упруго-пластическая с отвердением. Приведено описание методики численных исследований и ее программной реализации. Установлено, что при увеличении жесткости сминаемых вставок зависимость между нагрузкой и деформированием опоры в упругой и пластической стадиях имеет линейных характер. Выявлено также значительное снижение динамической реакции и увеличение времени деформирования податливых опор при увеличении их пластической составляющей, что позволяет рекомендовать их к применению в качестве опорных устройств для железобетонных изгибаемых и сжато-изгибаемых конструкций.
\end{abstract}

Ключевые слова: податливые опоры, прочность, деформативность, численное моделирование, метод конечных элементов, неявная схема интегрирования, нелинейные эффекты 


\section{INTRODUCTION}

Explosive impacts refer to single emergency loads. They are characterized by short term of action but high intensity which results not only in structural failure but also in production facilities damage and human losses. The existing approaches to designing building structures resistive to explosive impacts are based on increasing the material consumption of structures, which leads to increasing the cost of objects. Therefore, the elaboration of alternative economically feasible and reliable approaches is required to design structures that are resistant to intensive dynamic loads.

Yielding supports are one of the active means of structural protection, based on prevention or localization of dynamic impact or reducing the intensity of dynamic loading [1-9].

Currently, research results in the field of yielding supports application for protection of buildings and structures subjected to intensive dynamic loading are fragmentary. Experimental, theoretical and experimental-theoretical research [1-9] demonstrate both positive and possible negative influence of yielding supports on the dynamic response of RC beams. The object of the present study is numerical study of the strength and deformation property of yielding supports given as the tubes of annular section under static and short-term dynamic loading.

\section{METHODOLOGY FOR CONDUCTING NUMERICAL SIMULATION OF YIELDING SUPPORTS UNDER STATIC LOADING}

Finite element method (FEM) is certainly one of the dominant modern techniques of numerical simulation of such 3D nonlinear (physically, geometrically and structurally) static objectives; therefore it was selected as the basic one for conducting the present studies.

Program software Ansys Mechanical, v 17.2. was used as a software package realizing FEM in the given statement. The first stage of the work included analysis of yielding supports under quasi-static loading with the constant loading velocity. The design model was idealized and formalized copy of the physical reality and it duplicated the experimental study with a large accuracy [1] (Fig. 1).

Finite element model consisted of the two slabs, one of them was supporting and motionless, the second slab served as a force slab and it had the capacity of vertical displacement. The third element of the model was yielding support. Sample spacing of the finite element mesh of the slabs was $4 \mathrm{~mm}$, of the yielding support $0.8 \pm 0.1 \mathrm{~mm}$. The volume eight-node finite element SOLID185 was used as a finite element. Each finite element node is defined by three translational degrees of freedom and includes the possibility of using plastic materials and is also able to withstand larger deformations.

The model uses low-order finite elements (hsimulation technique). The analysis was performed for all the considered lengths of yielding supports in the range from 10 to 120 mm (Fig. 2).

The dimensions of the solved objective depending on the length of yielding support varied from 5664 to 58464 finite elements.

The work of material of yielding support was described by multilinear diagram of material straining with isotropic hardening. It was obtained by preliminary field experimental study of material under tension.

The loading of yielding support (rigid, kinematic) was performed by means of the given displacement of the upper slab (Fig. 1) to the distance corresponding to the inner diameter of yielding support.

\section{RESULTS OF NUMERICAL SIMULATION OF YIELDING SUPPORTS UNDER STATIC LOADING}

Let us consider the distinctive features of yielding supports straining on the example of inserted element of annular cross-section $40 \mathrm{~mm}$ long (Fig. 3). As can be observed, for all the sta- 
Numerical Simulation of Yielding Supports in the Shape of Annular Tubes Under Static and Short-Term Dynamic Loading

a)

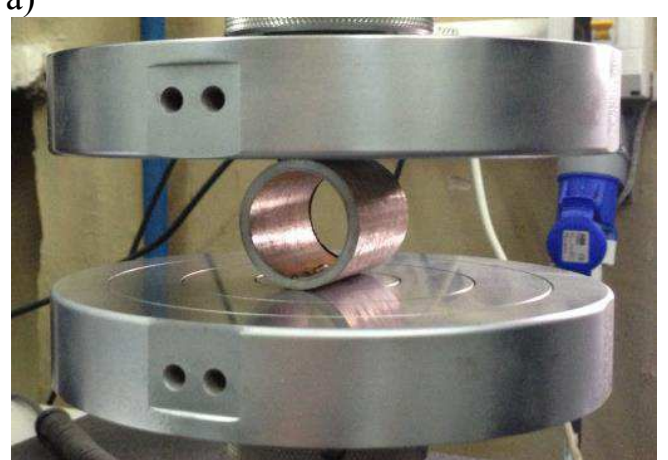

b)



Figure 1. The general view of yielding supports field tests (a); numerical simulation (b); 1 - supporting slab; 2 - reinforced slab; 3 - yielding support.

d)



e)

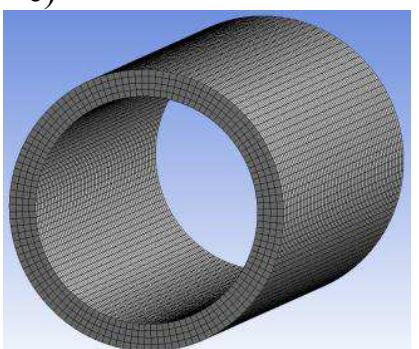

f)

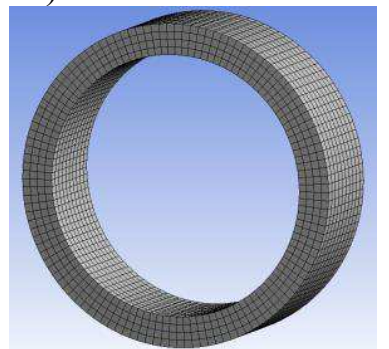

Figure 2. The general view of flexible bearings of various length: experimental studies $(a ; b ; c)$; numerical finite element model (d, e; f): $120 \mathrm{~mm}(a, d) ; 60 \mathrm{~mm}(b, e) ; 10 \mathrm{~mm}(c, f)$.

a)

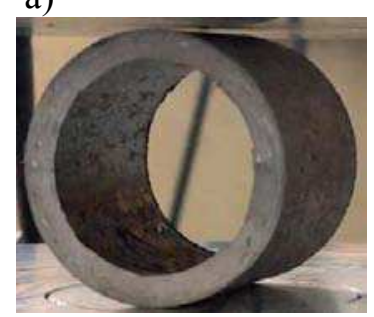

e)

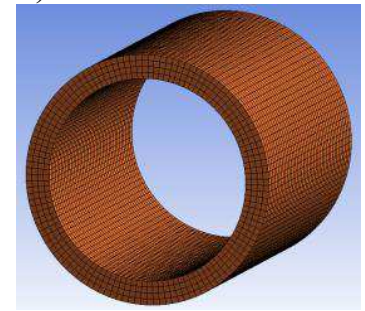

b)

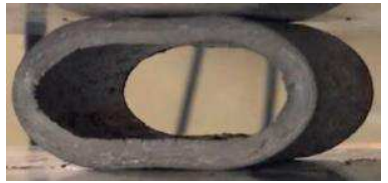

f) c)

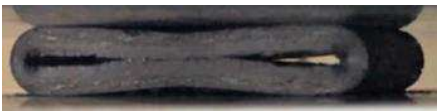

g)
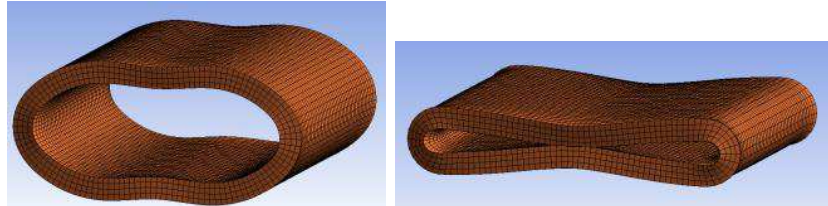

d)

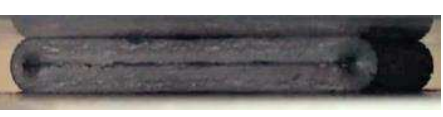

h)

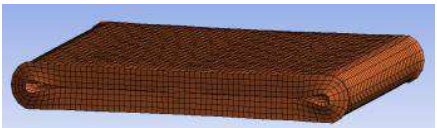

Figure 3. Peculiar stages of yielding supports deformation: elastic $(a, e)$; elasto-plastic $(b, f)$; elasto-plastic with hardening $(c, g, d, h)$

ges of yielding support work the strain pattern during field test corresponds to the strain pattern during numerical simulation.

The geometry of the studied sample during loading significantly changes its shape several times (Fig. 3) and the rigidity accordingly.
Considering that fact, the model was supplemented with the option of finite displacements consideration and angular displacements after each equilibrium iteration (geometrical nonlinearity). During straining process (Fig. 3), the yielding support interacts 
a)

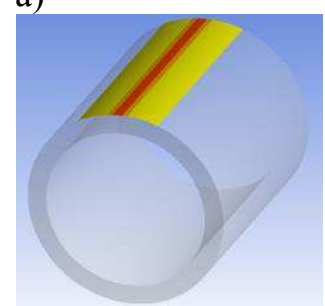

b)

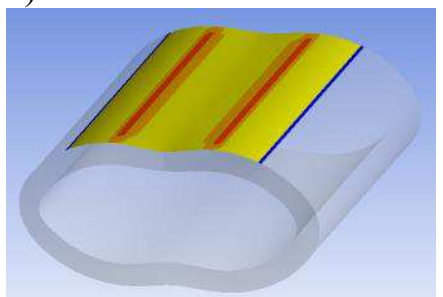

c)

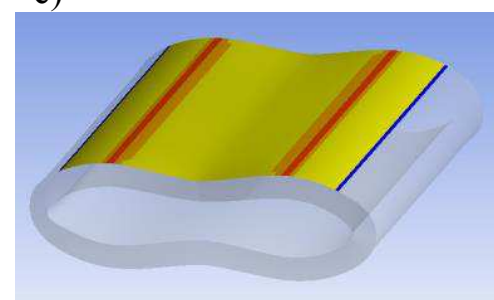

Figure 4. Alteration of the design model of yielding support in the process of straining: one contact point (line) with the slab (a); two contact points with the slab $(b, c)$.

with the force slabs changing its design model several times. After occurrence of the plastic strain in the yielding support, the contact point with each of the force slabs is divided in two. Then, along with the load increase, the contact points distribute from the center of the support to its edges (Fig. 4). In order to consider the above-mentioned process contacting pairs were established in the model between the inserted element and the force slabs, as well as between the internal surfaces of the yielding support. The blue color in Figure 7 identifies the contact elements, which are significantly remote from the contact surface. Contact elements, which are rather close to the contacting surface, are marked with yellow color. The red color identifies contact elements interacting with the contact surface, the force slab in particular.

Moreover, during yielding supports straining the contact of inner surfaces of the ring occurs (Fig. $3 \mathrm{c}, \mathrm{g}$ ), which in its turn alters the simulation model one more time. Further, the internal surfaces come into full contact (Fig. $3 \mathrm{~d}, \mathrm{~h}$ ).

It was established, that during straining process distortion of the ends of yielding support occurs in the areas of plastic hinge. Thus, the contact of internal surfaces of the ring occurs not simultaneously and from the ends to the middle part (Fig. 5).

As a contact interaction interface for all contacting pairs the model of contact with friction $\mu=0.15$ was used. This model includes the possibility to divide contacting pairs after interaction and generally can contain the areas of cohesion and sliding. Augmented Lagrangian method was applied for solution of contact interaction; it is based on the dependency of contact force on the penetration value (1):

$$
F_{n}=k_{n} x_{p}+\lambda
$$

where: $k_{n}-$ contact stiffness directed from normal to the surface, $x_{p}-$ the value of penetration along the normal to the surface, $\lambda-$ the augend reducing sensitivity to the value of contact. Simultaneous linear equations method was used for solution of the given objective (2):

$$
[K]\{u\}=\{F\},
$$

where, $[K]$ - system stiffness matrix, $\{u\}-$ the unknown vector of nodal displacements, $\{\mathrm{F}\}-$ the vector of the given external forces.

Checking the solution of non-linear problem was conducted using the Newton-Raphson method based on the equilibrium equation (3):

$R=\left\|F_{e x t}-F_{\text {int }}\right\|_{2}=\sqrt{\sum_{i=0}^{N}\left(F_{e x t, i}-F_{\text {int }, i}\right)^{2}}$.

where, $\mathrm{R}$ - the difference between the external and internal force vectors, $F_{\text {ext }}$ - external force vector, $\mathrm{F}_{\text {int }}$ - internal force vector, $\mathrm{N}$ - the number of vector elements, equal to the amount of degrees of freedom of FEM. During solving the objective of static loading of the yielding supports, the solution admitted computational error of 5\% between internal and external forces. Along with the increase in the number of elements in the solved objective in order to 
Numerical Simulation of Yielding Supports in the Shape of Annular Tubes Under Static and Short-Term Dynamic Loading

a)

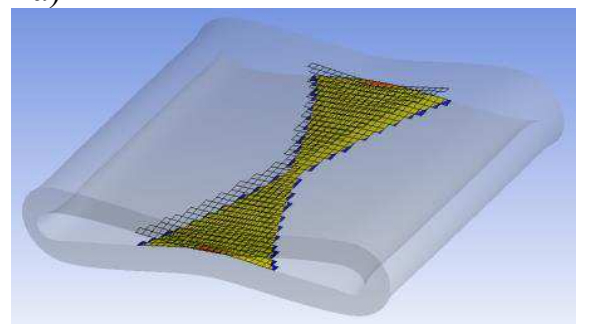

c)

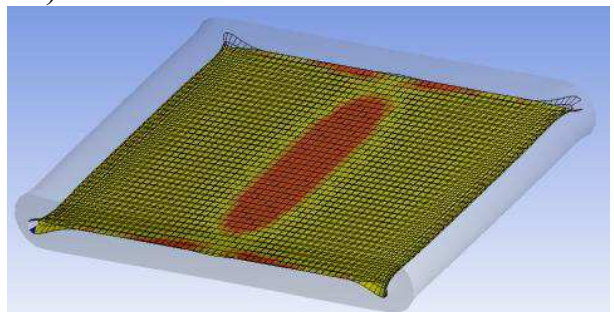

b)

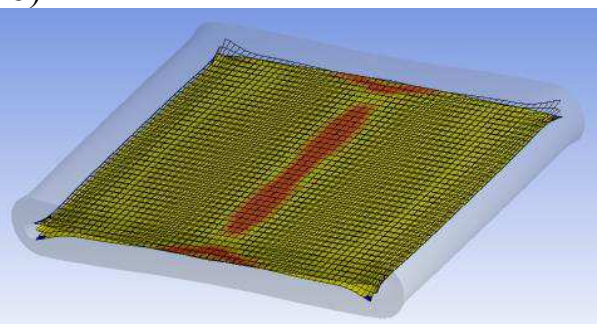

d)

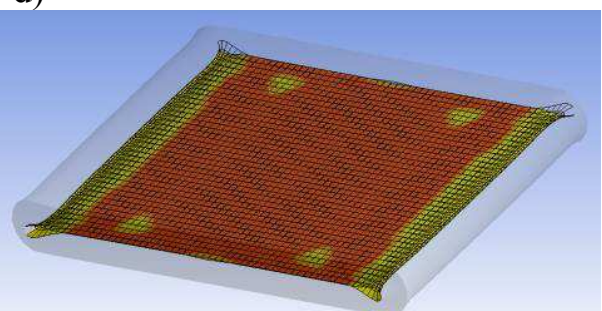

Figure 5. Alteration in the design model of yielding support during straining: impact of contacting pairs at the edges (a); contact of internal surfaces in the mid-area (b); gradual increase of the contact spot in the middle area (c); full contact of the internal surfaces (d).

a)

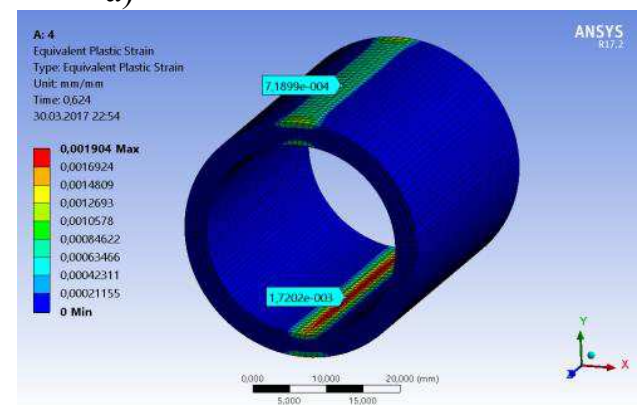

c)

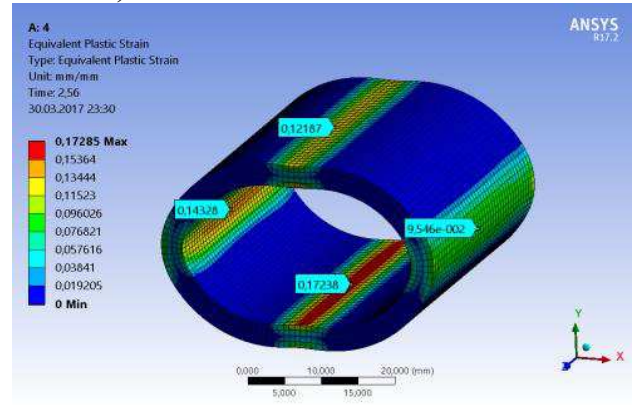

b)

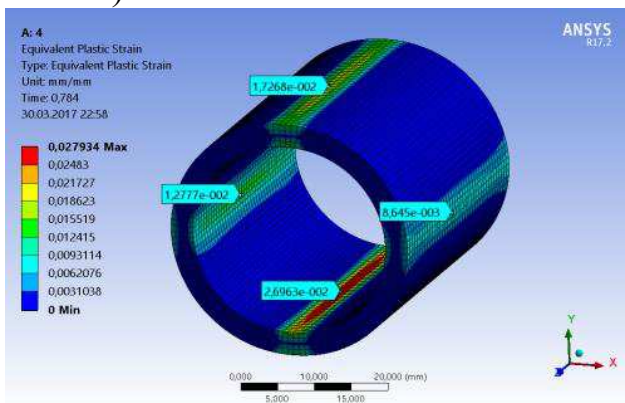

d)

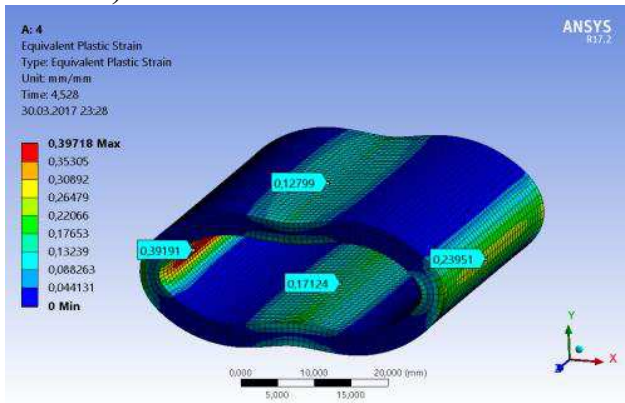

Figure 6. Distribution pattern of the plastic strain in the yielding support.

provide high accuracy, the proportional increase in the number of equilibrium iterations was required. Thus, the objectives considered from 500 to 8000 iterations. Analysis of the results of numerical simulation demonstrated that significant straining of yielding supports occurs due to formation of plastic hinges when the stresses in the material reach the yield stress.
These areas are first established in the upper and lower areas of the rings (Fig. 6a), and then at the lateral surfaces of the sample (Fig. 6b). Further straining is accompanied by the gradual growth of plastic strain and increasing the area of active straining. It should be noted that the value of relative strain at the internal lateral surface of the yielding support $\varepsilon>39 \%$ (Fig. $6 d$ ), 


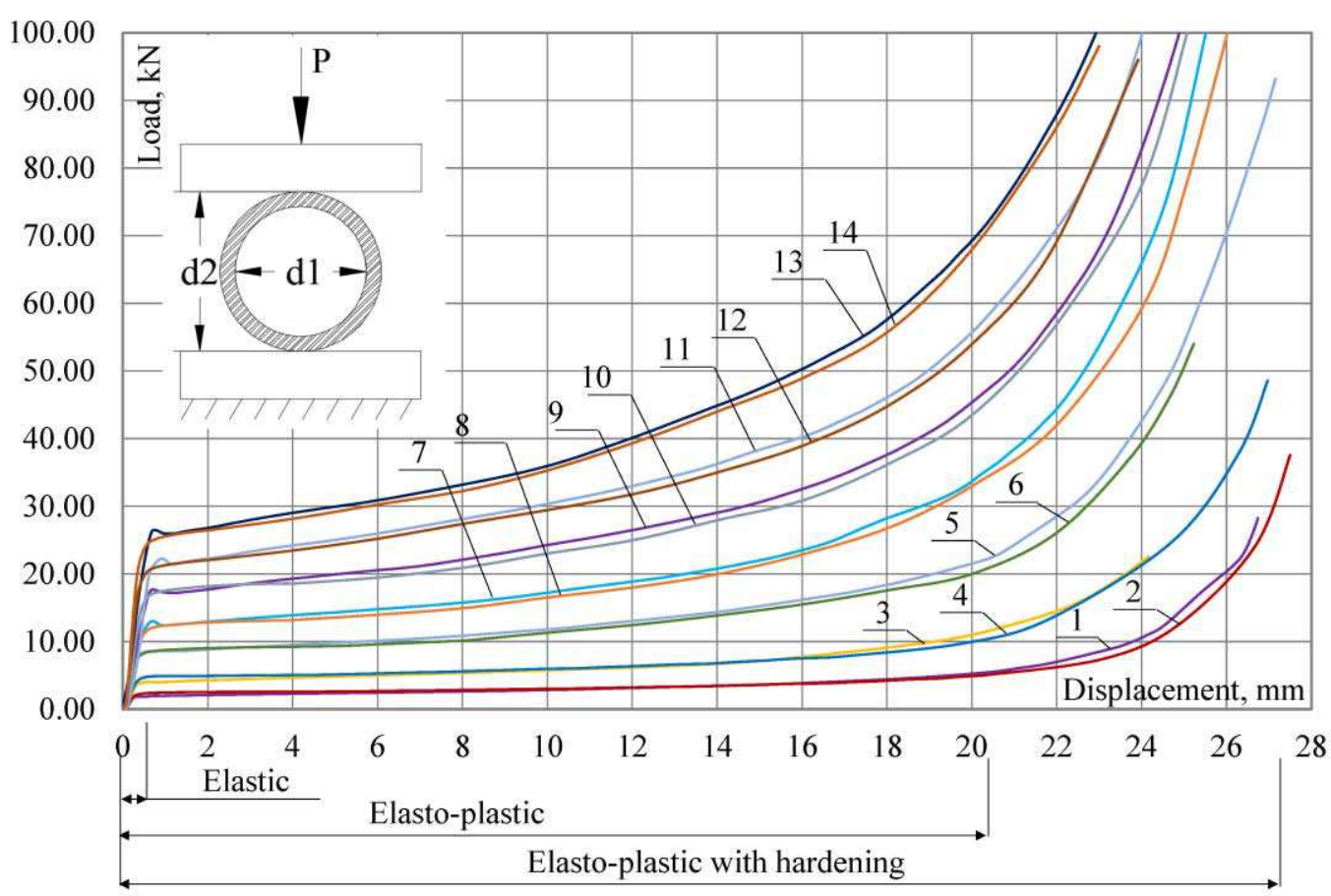

Figure 7. The strain diagram of yielding supports of various length under numerical and experimental study; d1-inner diameter; d2-outer diameter of the yielding supports; the uneven numbers correspond to the experimental studies; the even numbers present numerical simulation. 1-2- $10 \mathrm{~mm}$; 3-4- $20 \mathrm{~mm}$; 5-6- $40 \mathrm{~mm}$; 7-8 $60 \mathrm{~mm}$; 9-10-80 mm; 11-12- $100 \mathrm{~mm} ; 13-14-120 \mathrm{~mm}$.

which exceeds the ultimate strain of the steel $255 \varepsilon_{\mathrm{s}} 255>26 \%$. The mentioned area of straining undergoes compressive strain and due to curvilinear geometry of the sample, these locations are marked by the materials selfhardening effect.

Analysis of the results of numerical and experimental studies under quasi-static loading can be conducted based on the strain diagram of yielding supports (Fig. 7). Figure 7 illustrates the diagrams "load-displacement" for the yielding supports 10 and 20-120 mm long with the span of $20 \mathrm{~mm}$. According to the diagram, it can be judged on the close level of accordance of the experimental and numerical results at all stages of yielding supports performance.

Furthermore, with the increase of the yielding supports rigidity during experimental studies the strain diagrams are marked with the "yield drop" during transition of the support work from elastic into plastic stage of hardening, however it was not observed at the diagrams of numerical simulation. This effect applies for the lowcarbon steel. The occurrence of the "yield drop" is attributed to the dislocation deformation mechanism. At the initial phase, the density of dislocations is insignificant to provide larger strain degree. After reaching the upper yield stress, the intensive formation of new dislocations begins resulting in decrease of stress. Software package Ansys v 17.2 does not consider the dislocation deformation mechanisms referring to micro-structural steel composition; therefore, it leads to the absence of the "yield drop" in Figure 7.

Along with that, the local inaccuracy of the absolute value of load between the experimental and numerical result does not exceed $3.5 \%$ and does not change significantly the general strain pattern of yielding support within the solution of the given objective. 
Numerical Simulation of Yielding Supports in the Shape of Annular Tubes Under Static and Short-Term Dynamic Loading

\section{METHODOLOGY FOR CONDUCTING NUMERICAL SIMULATION OF YIELDING SUPPORTS UNDER DYNAMIC LOADING}

Simulation of dynamic impact was conducted in the module Ansys v17.2 - explicit dynamic (explicit difference integration scheme in time for dynamic objectives). Explicit dynamic defines the time step considering the stability condition of Courant-Friedrichs-Lewy (4):

$$
\Delta t \leq f *\left[\frac{h}{c}\right]_{\min },
$$

where, $\Delta \mathrm{t}-$ the time step, $\mathrm{f}-$ Courant number ( $\mathrm{f}$ $<1), \mathrm{h}-$ the typical element size, $\mathrm{c}$ - the local sound velocity in the element material.

The objectives were solved using Lagrangian approach to the medium motion description.

The simulation of the yielding supports operation under short-term dynamic loading was aimed at assessing the influence degree of the yielding supports on the dynamic response of the system: falling weight - yielding support supporting slab (Fig. 8). The variable rigidity parameter in the work was changing the length of the deformable element. Cross-section and the material of yielding support were accepted in accordance with the experimental studies [1]. Within the present objective the moment of impact of the falling weight 1 on the yielding support 2 was simulated. The mass of the weight 1 corresponded to the weight used while experimental studies, which is $265 \mathrm{~kg}$. For that purpose, the density of the weight was increased for each of the solved objectives.

The velocity of the weight 1 at the moment of impact on the yielding support 2 corresponded to the velocity of weight dropped from the height of $650 \mathrm{~mm}$ during experimental studies. The velocity of the weight 1 at the moment of impact on the yielding support 2 was calculated according to the dependence (1) obtained from the formulas for uniformly accelerated straight line motion (5) and was $3.57 \mathrm{~m} / \mathrm{s}$.

$$
S_{x}=\frac{V_{x}^{2}-V_{0}^{2}}{2_{a x}},
$$

where: $\mathrm{S}_{\mathrm{x}^{-}}$the height of falling weight $(0.65 \mathrm{~m})$, $\mathrm{V}^{2} \mathrm{x}^{-}$squared velocity at the impact moment of falling weight 1 and yielding support $2, \mathrm{~V}^{2} 0^{-}$ squared initial velocity of falling weight $1(0$ $\mathrm{m} / \mathrm{s}^{2}$ - the weight is suspended), $a_{\mathrm{x}}$ - acceleration of weight 1 (corresponds to gravity acceleration $\left.9.81 \mathrm{~m} / \mathrm{s}^{2}\right)$.

The supporting plate 3 was rigidly fixed along all degrees of freedom. Weight 1 and supporting plate 3, due to their small thickness in the model (Fig. 8 b), were accepted as completely rigid elements.

In the present work, three distinctive types of supports were considered (Fig. 9): a - elastic support; $\mathrm{b}$ - yielding support, working in elastoplastic stage with hardening, c - yielding support, working in elasto-plastic stage.

\section{RESULTS OF NUMERICAL SIMULATIONS OF YIELDING SUPPORTS UNDER DYNAMIC LOADING}

The degree of influence of the support rigidity can be evaluated from the diagram (Fig. 13). The first case (Fig. 9a) presents the elastic support, which possesses the properties of lowcarbon steel, which strains according to the Hooke's law. This support can be conventionally considered as elastic as the relative strain in it under dynamic loading will be changed according to the linear law with the constant deformation modulus corresponding to the steel elasticity modulus.

The support working in elasto-plastic with hardening stage (Fig. 9b) is characterized by the plastic straining with smooth increase in the dynamic response up to the moment when the internal surfaces of the supports contact (Fig. 10) and (Fig. 13b, point A). After that sharp increase in the value of dynamic response occurs.

Supports working in elasto-plastic stage (Fig. 9c), (Fig. 13 3,4), depending on their rigidity 
a)

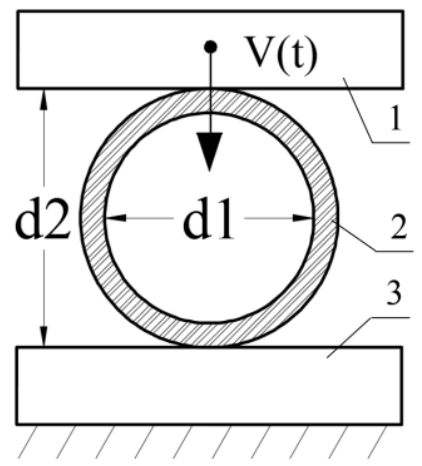

b)



Figure 8. Design model of the yielding support testing under short-term dynamic loading (a); general view of the finite element model (b); falling weight (1); yielding support (2); supporting slab (3); d1-inner diameter: d2-outer diameter.

a)

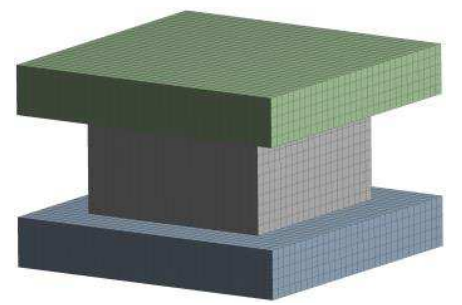

b)



c)

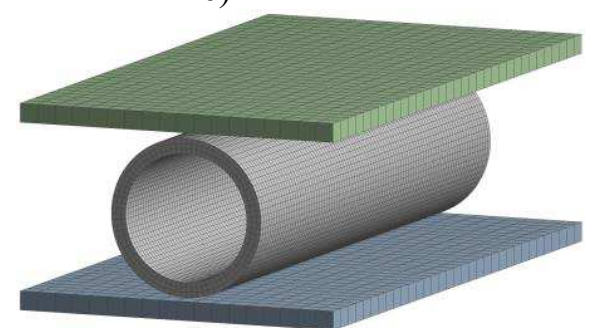

Figure 9. Computational finite element models of yielding support under short-term dynamic loading; elastic support (a); yielding support, working in elasto-plastic stage with hardening (b); yielding supports working in elasto-plastic stage $(c, d)$.

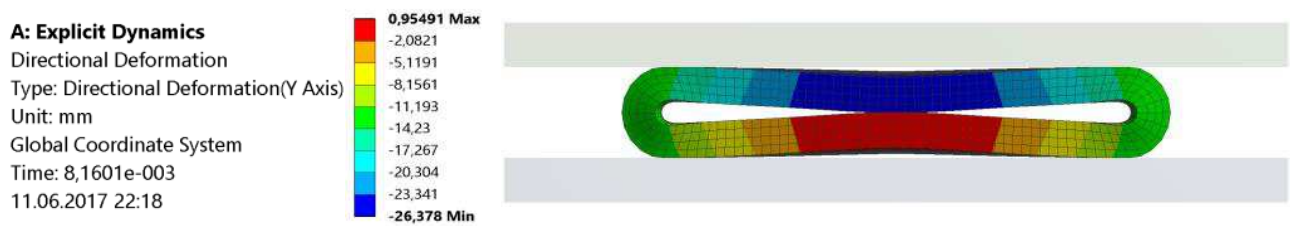

Figure 10. The overall scheme of the support straining, working in elasto-plastic with hardening stage, the moment of transition of the support into hardening stage point A (Fig. 13b).

can have different dynamic response diagrams. Along with the increase in plastic component of such supports increase in time of response occurs. Thus, for instance for the support 120 mm long (Fig. 134 ), compared to the support $1600 \mathrm{~mm}$ long (Fig. 13 3), the time of dynamic resistance increased by 2.66 times, which testifies on more plastic work of the first one. Moreover, the support of the larger length does not deplete the whole potential of its plastic properties (Fig. 11), while the support of the less length almost come into contact by the internal surfaces of the ring (Fig. 12). The decrease in the maximum value of dynamic response should be noted (Fig. 13 3, 4) from $407 \mathrm{kN}$ corresponding to the support $1600 \mathrm{~mm}$ long to $288 \mathrm{kN}$ for the support $120 \mathrm{~mm}$ long which makes $29.2 \%$.

Having compared the support work in elastoplastic stage (Fig. 133,4 ) and the support work in hardening stage (Fig. 13 2), the reduction of the system dynamic response by 6.4 times was observed (Fig. 13).

Conducting the analysis of yielding supports work (Fig. 13 2-4) with totally elastic support (Fig. 13 1), a significant reduction in the system 
Numerical Simulation of Yielding Supports in the Shape of Annular Tubes Under Static and Short-Term Dynamic Loading
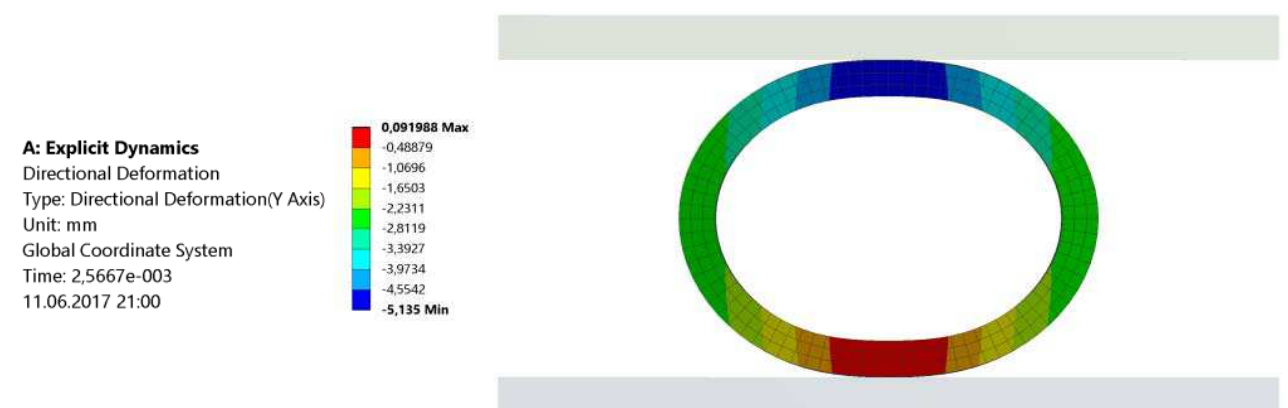

Figure 11. The general strain pattern of the support working in elasto-plastic stage (the length of the support $1600 \mathrm{~mm}$ ).


Figure 12. The general strain pattern of the support working in elasto-plastic stage (the length of the support $120 \mathrm{~mm}$ ).

a)

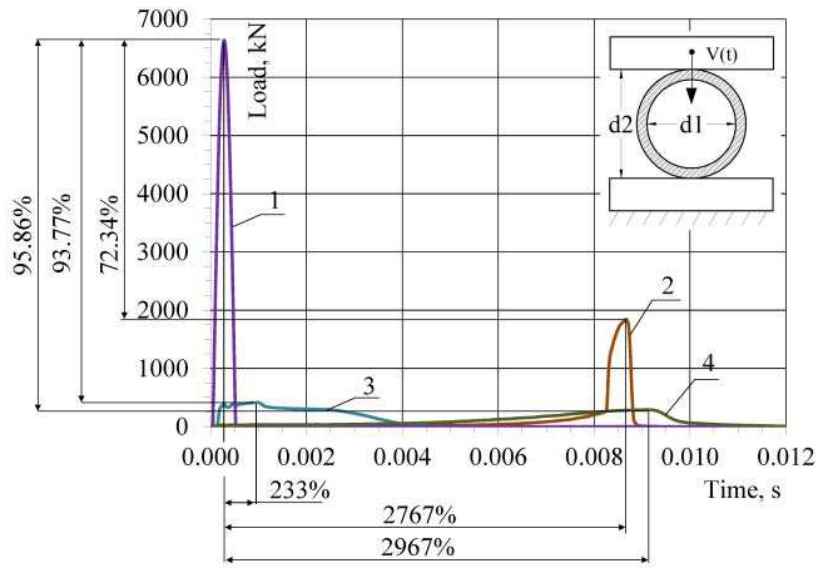

b)

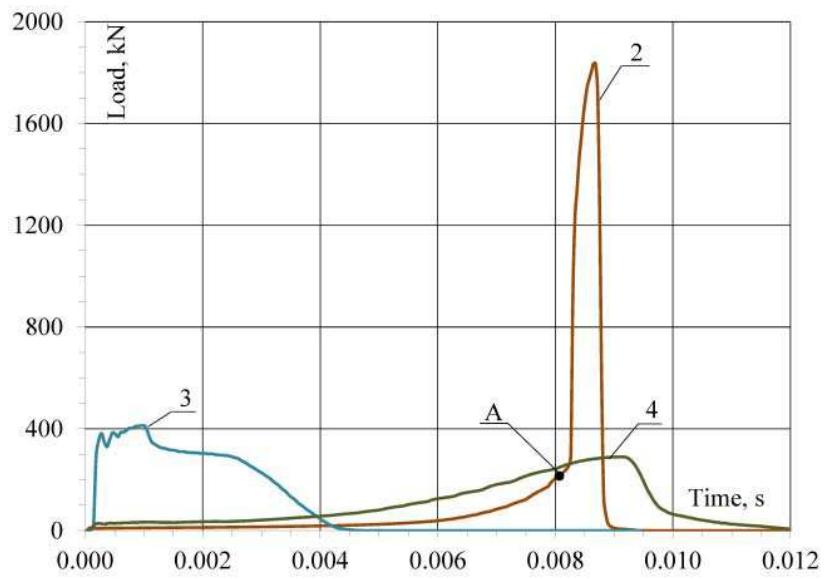

Figure 13. Diagram of changing in the dynamic response of the supports depending on their rigidity; totally elastic support (1); yielding support, working in elasto-plastic with hardening stage

(2); the moment of transition of yielding support into the hardening stage (A); yielding supports working in elasto-plastic stage $(3,4)$.

dynamic response was revealed, thus, for instance for the elasto-plastic support (Fig. 13 4 ), compared to the totally elastic support (Fig. 13 1) the reduction was 23.4 times, and for the elasto-plastic with hardening support it was 6.62 times. Along with that, one should note that the increase in the time of dynamic response for yielding supports compared to the totally elastic ones should be specified (Fig. 13). The time of straining for totally elastic supports was 0.0005 sec, while for the supports working in the hardening stage it was 0.009 , and for elastoplastic it was 0.012 , which is 18 and 24 times more than for the elastic supports accordingly.

\section{CONCLUSION}

Within the conducted research, the results of numerical and experimental studies of 
deformation of yielding supports in the shape of inserted elements of annular cross-section under static loading were compared. Results demonstrate high qualitative and quantitative coincidence of the used methods. Therefore it testifies on possibility of FEM application for solution of objectives with significant physical, geometrical and contact (structural) nonlinearities, being simultaneously present in one objective. Along with that, it should be noted that FEM application in research of nonlinear structural behavior under dynamic impact is an effective tool compared to the field tests. Field tests are generally hard or even impossible to implement while the obtained data is fragmentary and to a large extend limited by the measuring facilities.

Numerical simulation results found in the present paper also demonstrate high efficiency of yielding supports subjected to short-term dynamic loading as compared to traditional elastic supports. The required effect is reached due to the peculiarities of plastic straining of the annular section and increase in the time of dynamic straining. Therefore, the obtained results enable to judge on the possibility of yielding supports application aimed at the increase in the dynamic strength of RC beams.

\section{ACKNOWLEDGEMENT}

Authors acknowledge A.M. Belostotskii, D.Sc., I.N. Afanasieva, PhD and S.V. Scherbina, the research workers of ZAO Research Center StaDyO and Research and Educational Centre of Computer Modeling, Moscow State University of Civil Engineering for a significant assistance in studying the methodologies and program software for numerical simulation to one of the authors during his research internship.

The research was conducted with the support of the Russian Foundation for Basic Research; Project No. 16-38-00133.

\section{REFERENCES}

1. Kumpyak O.G., Meshcheulov N.V. Prochnost' szhato-izgibaemyh zhelezobetonnyh konstrukcij po naklonnym sechenijam na podatlivyh oporah pri dinamicheskom nagruzhenii [Strength of reinforced concrete beams on yielding supports along oblique sections under dynamic loading]. Vestnik of TSUAB, 2014, Number 6, pp. 70-80.

2. Poonaya S., Thinvongpituk C., Teeboonm U. An Analysis of Collapse Mechanism of Thin-Walled Circular Tubes Subjected to Bending. // Proceedings of WASET, 2007, Number 26, pp. 329-334.

3. Mata P., Barbat A., Oller S., Boroschek R. Constitutive and geometric nonlinear models for the seismic analysis of rc structures with energy dissipators. // Arch. comput. methods eng., 2008, Number 15, pp. 489-539.

4. Olabi A., Morris E., Hashmi M. Metallic tube type energy absorbers: A synopsis. // Journal of Thin-Walled Structures, 2008, Number 45, pp. 706-726.

5. Marzbanrad J., Mehdikhanlo M., Saeedi Pour A. An energy absorption comparison of square, circular, and elliptic steel and aluminum tubes under impact loading. // Turkish J. Eng. Env. Sci., 2009, Number 33, pp. 159-166.

6. Kumpyak O.G., Galyautdinov Z.R., Kokorin D.N. Strength of concrete structures under dynamic loading. // II AllRussian Scientific Conference of Young Scientists "Advanced Materials in Technology and Construction", 2015, Number 1698.

7. Chiaia B., Kumpyak O.G., Placidi L., Maksimov V.B. Experimental analysis and modeling of two-way reinforced concrete slabs over different kinds of yielding supports under short-term dynamic loading. // Engineering Structures, 2015, Number 96, pp. 88-99. 
Numerical Simulation of Yielding Supports in the Shape of Annular Tubes Under Static and Short-Term Dynamic Loading

8. Rastorguev V.S. Primenenie dinamicheskih gasitelej kolebanij pri vzryvnyh vozdejstvijah [Application of dynamic oscillation dampers under explosive impacts]. // Building mechanics and analysis of structures, 2009, Number 1, pp. 50-57.

9. Kumpyak O.G., Galyautdinov Z.R., Kokorin D.N. Prochnost' i deformativnost' zhelezobetonnyh konstrukcij na podatlivyh oporah pri kratkovremennom dinamicheskom nagruzhenii [Strength and deformability of reinforced concrete structures on yielding supports under shortterm dynamic loading]. Tomsk, TSUAB Publishing Office, 2016, 272 pages.

\section{СПИСОК ЛИТЕРАТУРЫ}

1. Кумпяк О.Г., Мещеулов Н.В. Прочность сжато-изгибаемых железобетонных конструкций по наклонным сечениям на податливых опорах при динамическом нагружении. // Вестник ТГАСУ, 2014, №6, c. 70-80.

2. Poonaya S., Thinvongpituk C., Teeboonm U. An Analysis of Collapse Mechanism of Thin-Walled Circular Tubes Subjected to Bending. // Proceedings of WASET, 2007, Number 26, pp. 329-334.

3. Mata P., Barbat A., Oller S., Boroschek R. Constitutive and geometric nonlinear models for the seismic analysis of rc structures with energy dissipators. // Arch. comput. methods eng., 2008, Number 15, pp. 489-539.

4. Olabi A., Morris E., Hashmi M. Metallic tube type energy absorbers: A synopsis. // Journal of Thin-Walled Structures, 2008, Number 45, pp. 706-726.

5. Marzbanrad J., Mehdikhanlo M., Saeedi Pour A. An energy absorption comparison of square, circular, and elliptic steel and aluminum tubes under impact loading. // Turkish J. Eng. Env. Sci., 2009, Number 33, pp. 159-166.
6. Kumpyak O.G., Galyautdinov Z.R., Kokorin D.N. Strength of concrete structures under dynamic loading. // II AllRussian Scientific Conference of Young Scientists "Advanced Materials in Technology and Construction", 2015, Number 1698.

7. Chiaia B., Kumpyak O.G., Placidi L., Maksimov V.B. Experimental analysis and modeling of two-way reinforced concrete slabs over different kinds of yielding supports under short-term dynamic loading. // Engineering Structures, 2015, Number 96, pp. 88-99.

8. Расторгуев В.C. Применение динамических гасителей колебаний при взрывных воздействиях. // Строительная механика и расчет сооружений, 2009, №1, c. 50-57.

9. Кумпяк О.Г., Галяутдинов 3.P., Кокорин Д.Н. Прочность и деформативность железобетонных конструкций на податливых опорах при кратковременном динамическом нагружении. - Томск: Издательство ТГАСУ, 2016. - 272 с.

Oleg G. Kumpyak, Tomsk State University of Architecture and Building, Reinforced Concrete and Masonry Structures, 634003, Russia, Tomsk, 2 Solyanaya sq., Building 5, e-mail: kumpyak@yandex.ru.

Nikita V. Mescheulov, Tomsk State University of Architecture and Building, Head of the Research and Education Center of Computer Simulation and Modeling of Building Structures and Systems, 634003, Russia, Tomsk, 2 Solyanaya sq., Building 1,

e-mail: nikita.mesheulov@mail.ru.

Кумпяк Олег Григорьевич, Томский государственный архитектурно-строительный университет, кафедра железобетонных и каменных конструкций 634003, Россия, г. Томск, Соляная площадь, 2 корпус 5, e-mail: kumpyak@yandex.ru.

Мещеулов Никита Владимирович, Томский государственный архитектурно-строительный университет, научно- образовательный центр компьютерного моделирования строительных конструкций и систем 634003, Россия, г. Томск, Соляная площадь, 2 корпус 1 ,

e-mail: nikita.mesheulov@mail.ru. 